\title{
ANALISIS PENGARUH PERTUMBUHAN EKONOMI, PENDAPATAN ASLI DAERAH, DANA PERIMBANGAN dan LAIN- LAIN PENDAPATAN YANG SAH TERHADAP BELANJA MODAL DI JAWA TIMUR
}

\author{
Diah Nurdiwaty $^{1}{ }^{*}$; Badrus Zaman $^{2}$; Efda Kristinawati ${ }^{3}$ \\ ${ }^{1,2,3}$ Universitas Nusantara PGRI Kediri \\ Korespondensi : ardh_olivia@yahoo.com
}

\begin{abstract}
The purpose of this study is to analyze the effect of, (1) Growth of the Appropriations Budget Capital Expenditure on Local Government of Regency / City in East Java province, (2) revenue (PAD against Appropriations Budget Capital Expenditure on Local Government of Regency/City in east Java, (3) the Balance Fund against Appropriations Budget Capital Expenditure on Local Government of Regency / City in east Java province, (4) other Revenues Legitimate against Appropriations Budget Capital Expenditure on Local Government of Regency / City in east Java province, (5) Economic Growth, Local Revenue (PAD), Balance Funds and other Revenues Legitimate against Appropriations Budget Capital Expenditure on Local Government of Regency / City in East Java province. Data analysis and hypothesis test using a statistical diskripstif to do classical assumption test and multiple linear regression. The research sample is "totaling sampling" 114 Regency / City. The results of this study are partially showed that the variables Economic Growth and Other Income Legitimate no significant effect on capital expenditure budget allocation. While the Local Revenue and Fund Balance significant effect on capital expenditure budget allocation. While the study was conducted simultaneously Growth, PAD, DBH and Other Income Legitimate significant effect on capital expenditure budget allocation.
\end{abstract}

Keywords: Economic Growth, Local Revenue, Balance Funds, Others Legitimate Income, Capital Expenditure

\begin{abstract}
ABSTRAK
Tujuan penelitian ini adalah menganalisis pengaruh, (1) Pertumbuhan Ekonomi, (2) Pendapatan Asli Daerah, (3) Dana Perimbangan terhadap, (4) Lain-lain Pendapatan yang Sah, (5) Pertumbuhan Ekonomi, Pendapatan Asli Daerah (PAD), Dana Perimbangan dan Lain-lain Pendapatan yang Sah, terhadap Pengalokasian Anggaran Belanja Modal pada Pemerintah Daerah Kabupaten/ Kota di Provinsi Jawa Timur. Analisis data dan pengujian hipotesis dilakukan menggunakan statistik diskriptif melalui uji asumsi klasik dan regresi linear berganda. Sampel penelitian ini adalah totaling sampling yaitu 114 Kabupaten/ Kota. Hasil penelitian secara parsial menunjukkan bahwa variabel Pertumbuhan Ekonomi dan Lain-lain Pendapatan yang Sah tidak berpengaruh signifikan terhadap pengalokasian anggaran belanja modal. Sedangkan Pendapatan Asli Daerah dan Dana Perimbangan berpengaruh signifikan terhadap pengalokasian anggaran belanja modal. Sedangkan Penelitian yang dilakukan secara simultan Pertumbuhan Ekonomi, Pendapatan Asli Daerah, Dana Perimbangan, dan Lainlain Pendapatan yang Sah berpengaruh signifikan terhadap pengalokasian anggaran belanja modal.
\end{abstract}

Kata Kunci: Pertumbuhan Ekonomi, Pendapatan Asli Daerah (PAD), Dana Perimbangan, Lain lain Pendapatan yang Sah, Belanja Modal DOI: 10.20885/jabis.vol17.iss1.art3 


\section{PENDAHULUAN}

Standar Akuntansi Pemerintah (SAP), menyatakan bahwa Anggaran merupakan pedoman tindakan yang akan dilaksanakan pemerintah meliputi rencana pendapatan, belanja, transfer, dan pembiayaan yang diukur dalam satuan rupiah, yang disusun menurut klasifikasi tertentu secara sistematis untuk satu periode. Anggaran daerah merupakan rencana keuangan yang dijadikan pedoman bagi pemerintah daerah dalam pelaksanaan pelayanan publik. Di Indonesia, dokumen anggaran daerah sering disebut Anggaran Pendapatan dan Belanja Daerah (APBD), baik untuk provinsi maupun kota atau kabupaten.

Provinsi Jawa Timur merupakan salah satu provinsi yang telah menerapkan otonomi daerah dengan landasan Undang-Undang Nomor 32 Tahun 2004 tentang Pemerintahan Daerah yang telah diubah menjadi Undang-Undang Nomor 23 Tahun 2014, merujuk pada UU tersebut bahwa otonomi daerah adalah hak, wewenang, dan kewajiban daerah otonom untuk mengatur dan mengurus sendiri urusan pemerintahan dan kepentingan masyarakat setempat sesuai dengan peraturan perundangundangan. Otonomi daerah bertujuan untuk mempercepat pembangunan daerah dan laju pertumbuhan ekonomi, mengurangi kesenjangan antar daerah, dan meningkatkan pelayanan publik. Otonomi daerah yang terjadi bukan hanya penyerahan tugas dari pemerintah pusat ke pemerintah daerah, tetapi juga disertai dengan pelimpahan wewenang untuk dapat mengelola pemerintahannya sendiri. Diberlakukannya otonomi daerah memberikan kesempatan pemerintah daerah untuk lebih mengembangkan potensi daerah. Untuk mengembangkan potensi daerah tersebut maka pemerintah daerah perlu meningkatkan anggaran belanja modal, sumber-sumber dana yang digunakan untuk membiayai belanja modal tersebut terdiri dari Pendapatan Asli Daerah (PAD), Dana Perimbangan, Lain-lain Pendapatan yang Sah hal tersebut sesuai Undang-Undang No. 33 Tahun 2004.

Penyelenggaraan fungsi pemerintahan daerah akan terlaksana dengan optimal apabila penyelenggaraan urusan pemerintahan diikuti dengan pemberian sumber-sumber penerimaan yang cukup kepada daerah. serta bersandar pada Undang-Undang tentang Perimbangan Keuangan antara Pemerintah Pusat dan Pemerintahan Daerah. Semua sumber keuangan yang melekat pada setiap urusan pemerintah yang diserahkan kepada daerah menjadi sumber keuangan daerah. Undang-Undang No. 33 Tahun 2004 tentang Perimbangan Keuangan antara Pemerintah Pusat dan Pemerintah Daerah BAB I Pasal 1 ayat 3 bahwa Perimbangan keuangan antara pemerintah pusat dan pemerintah daerah adalah suatu sistem pembagian keuangan yang adil, proporsional, demokratis, transparan, dan efisien dalam rangka pendanaan penyelenggaraan desentralisasi, dengan mempertimbangkan potensi, kondisi, dan kebutuhan daerah, serta besaran pendanaan penyelenggaraan dekonsentrasi dan tugas pembantu.

Pertumbuhan ekonomi menunjukkan sejauh mana aktivitas perekonomian akan menghasilkan tambahan pendapatan masyarakat pada suatu periode tertentu. Meningkatkan produksi barang dan 
jasa dari suatu daerah, secara makro dapat dilihat dari peningkatan nilai Produk Domestik Regional Bruto (PDRB) setiap tahunnya dan secara mikro dilihat dari Produk Domestik Regional Bruto perkapitanya. PDRB dalam stastistik disajikan dalam dua penilaian, yaitu atas harga berlaku (at current market) yaitu PDRB yang memasukkan faktor inflansi di dalamnya dan atas dasar harga konstan (at constant market price) yaitu PDRB yang sudah mengeliminasi faktor inflasi.

Desentralisasi fiskal memberikan kewenangan yang besar kepada daerah untuk menggali potensi yang dimiliki sebagai sumber pendapatan daerah untuk membiayai pengeluaran daerah dalam rangka pelayanan publik. Sumber pendapatan daerah adalah Pendapatan Asli Daerah (PAD), Dana Perimbangan, dan Lain-lain Pendapatan yang sah. Peningkatan PAD, Dana Perimbangan, dan Lainlain Pendapatan yang Sah diharapkan dapat meningkatkan investasi belanja modal pemerintah daerah sehingga kualitas pelayanan publik semakin baik. Setiap daerah mempunyai kemampuan keuangan yang tidak sama dalam mendanai kegiatan-kegiatannya, hal ini menimbulkan ketimpangan fiskal antara satu daerah dengan daerah lainnya. Oleh karena itu, untuk mengatasi ketimpangan fiskal ini Pemerintah mengalokasikan dana yang bersumber dari APBN untuk mendanai kebutuhan daerah dalam pelaksanaan desentralisasi. Dana perimbangan dari pemerintah ini yang pengalokasiannya menekankan aspek pemerataan dan keadilan yang selaras dengan penyelenggaraan urusan pemerintahan (UU 32/2004). Dengan adanya transfer dana dari pusat ini diharapkan pemerintah daerah bisa lebih mengalokasikan PAD yang didapatnya untuk membiayai belanja modal di daerahnya.

Belanja modal merupakan salah satu cara untuk mewujudkan tujuan otonomi daerah yaitu meningkatkan kesejahteraan dan pelayanan kepada masyarakat, hal ini menyimpulkan bahwa belanja modal itu sangat penting karena membantu mewujudkan kesejahtraan masyarakat. Pergeseran komposisi belanja merupakan upaya logis yang dilakukan pemerintah daerah setempat dalam rangka meningkatkan tingkat kepercayaan publik. Pergesaran ini ditujukan untuk peningkatan investasi modal dalam bentuk aset tetap, yaitu peralatan, bangunan, infrastruktur, dan harta tetap lainnya. Semakin tinggi tingkat investasi modal diharapkan mampu meningkatkan kualitas layanan publik, karena aset tetap yang dimiliki sebagai akibat adanya belanja modal merupakan prasyarat utama dalam memberikan pelayanan publik oleh pemerintah daerah. Oleh karena itu Pemerintah daerah mengalokasikan dana dalam bentuk anggaran belanja modal dalam APBD untuk menambah aset tetap. Alokasi belanja modal ini didasarkan pada kebutuhan daerah akan sarana dan prasarana, baik untuk kelancaran pelaksanaan tugas pemerintahan maupun untuk fasilitas publik.

Berdasarkan uraian diatas penulis tertarik untuk meneliti Pertumbuhan Ekonomi, Pendapatan Asli Daerah (PAD), Dana Perimbangan dan Lain-Lain Pendapatan Yang Sah, yang diharapkan dapat memberikan informasi yang besar dalam peningkatan Pengalokasian Anggaran Belanja Modal sehingga dapat mensukseskan pembangunan daerah. Maka dalam penelitian ini mengambil judul: 
"Analisis Pengaruh Pertumbuhan Ekonomi, PAD, Dana Perimbangan dan Lain-lain Pendapatan Yang Sah Terhadap Belanja Modal Kabupaten/Kota di Jawa Timur”.

\section{TINJAUAN PUSTAKA}

\section{Akuntansi Pemerintahan}

Menurut Peraturan Pemerintah Republik Indonesia Nomor 71 Tahun 2010 tentang Standar Akuntansi Pemerintahan BAB I Pasal 1 ayat 3, menyatakan bahwa Standar Akuntansi Pemerintahan yang selanjunya disebut SAP adalah prinsip-prinsip akuntansi yang diterapkan dalam menyusun dan menyajikan laporan keuangan pemerintah. Laporan keuangan pemerintah disusun untuk memenuhi kebutuhan informasi dari dari semua kelompok pengguna (Nordiawan (2009:128). Menurut Baswir (2000:7) bahwa Akuntansi Pemerintahan (termasuk di dalamnya akuntansi untuk lembagalembaga yang tidak bertujuan mencari laba lainnya), adalah bidang akuntansi yang berkaitan dengan lembaga-lembaga pemerintahan dan lembaga-lembaga yang tidak bertujuan mencari laba.

Peraturan Pemerintah Republik Indonesia No. 71 tahun 2010 Standar Akuntansi Pemerintahan menyatakan bahwa Laporan keuangan pokok terdiri atas: 1) Laporan Realisasi Anggaran, 2) Laporan Perubahan Saldo Anggaran Lebih, 3) Neraca, 4) Laporan Operasional, 5) Laporan Arus Kas, 6) Laporan Perubahan Ekuitas, 7) Catatan atas Laporan Keuangan.

Menurut Nordiawan (2009:128) Laporan keuangan pemerintah disusun untuk memenuhi kebutuhan informasi dari dari semua kelompok pengguna. Meliputi 1) masyarakat, 2) wakil rakyat, 3) lembaga pemeriksa dan lembaga pengawas, 4) Pihak yang memberi atau berperan dalam proses donasi, investasi, dan pinjaman, 5) Pemerintah.

\section{Regulasi Akuntansi Pemerintahan}

Menurut Andayani (2007:6) Istilah akuntansi sektor publik baru diperhatikan setelah adanya semangat untuk berotonomi daerah dan keinginan bertransparasi sekitar tahun 1999. Regulasi yang mengatur hal tersebut adalah undang-undang dan peraturan pemerintah yang mendukung pelaksanaan otonomi daerah dan desentralisasi.

1. UU No. 22 Tahun 1999 disempurnakan dengan UU No. 32 Tahun 2004 tentang Pemerintah Daerah

2. UU No. 5 Tahun 1999 telah di sempurnakan dengan diterbitkannya UU No. 33 Tahun 2004 tentang Perimbangan Keuangan antara Pemerintah Pusat dan Pemerintah Daerah.

3. PP No. 104 Tahun 2000 yang diubah dengan PP No. 55 Tahun 2005 tentang Dana Perimbangan 
4. PP No. 105 Tahun 2000, yang diubah dengan PP No. 58 tahun 2005 tentang Pengelolaan dan Pertanggungjawaban Keuangan Daerah.

5. PP No. 106 Tahun 2000 tentang Pengelolaan dan Pertanggungjawaban Keuangan dalam Pelaksanaan Dekonsentrasi dan Tugas Pembantuan.

6. PP No. 107 Tahun 2000, yang diubah dengan PP No. 54 Tahun 2005 tentang Pinjaman Daerah.

7. PP No. 108 Tahun 2000 tentang Tata Cara Pertanggungjawaban Kepala Daerah.

8. PP No. 109 Tahun 2000 tentang Kedudukan Keuangan Kepala Daerah dan Wakil Kepala Daerah.

9. PP No. 110 Tahun 2000 tentang Kedudukan Keuangan Dewan Perwakilan Rakyat Daerah.

10.UU No. 17 Tahun 2003 tentang Keuangan Negara

11.PP No. 23 Tahun 2003 tentang Pengendalian Jumlah Kumulatif Defisit Anggaran Pendapatan dan Belanja Negara dan Anggaran Pendapatan dan Belanja Daerah, serta jumlah Kumulatif Pinjaman Pemerintah Pusat dan Pemerintah Daerah. Penekanan peraturan ini hanya pada pengendalian jumlah kumulatif pinjaman.

12.UU No. 1 Tahun 2004 tentang Perbendaharaan Negara

13.UU No. 15 Tahun 2004 tentang Pemeriksaan Pengelolaan dan Tanggung Jawab Keuangan Negara

14.UU No. 25 Tahun 2004 tentang Sistem Perencanaan Pembangunan Nasional

15.PP No. 23 Tahun 2005 tentang Pengelolaan Keuangan Badan Layanan Umum

16.PP Nomor 24 Tahun 2005 tentang Standar Akuntansi Pemerintahan.

17.PP Nomor 56 Tahun 2005 tentang Sistem Informasi Keuangan Daerah.

18.PP Nomor 57 Tahun 2005 tentang Hibah Kepada Daerah.

19.PP Nomor 58 Tahun 2005 tentang Pengeloalaan Keuangan Daerah.

20.PP Nomor 65 Tahun 2005 tentang Pedoman Penyusunan dan Penerapan Standar Pelayanan Minimal.

21.Pemendagri No. 13 Tahun 2006 tentang Pedoman Pengelolaan Keuangan Daerah.

22.PP No. 71 Tahun 2010 tentang Standar Akuntansi Pemerintahan

23.Pemendagri No. 64 Tahun 2013 tentang Penetapan Standar Akuntansi Pemerintahan Berbasis Akrual

24.UU No. 23 Tahun 2014 tentang Pemerintah Daerah

\section{Anggaran Pendapatan Belanja Daerah (APBD)}

Menurut Nordiawan (2007:39) disampaikan bahwa Anggaran Pendapatan dan Belanja Daerah (APBD) merupakan rencana keuangan tahunan pemerintah daerah yang disetujui oleh DPRD dan ditetapkan dengan peraturan daerah. Merujuk pada Peraturan Pemerintah Republik Indonesia Nomor 
64 tahun 2013 tentang Penetapan Standar Akuntansi Pemerintahan Berbasis Akrual Pada Pemerintah Daerah BAB I Pasal 1dinyatakan bahwa Anggaran Pendapatan dan Belanja Daerah, selanjutnya disingkat APBD adalah rencana keuangan tahunan pemerintahan daerah yang dibahas dan disetujui bersama oleh pemerintah daerah dan DPRD, dan ditetapkan dengan peraturan daerah. Sesuai Peraturan Republik Indonesia Nomor 58 Tahun 2005 tentang Pengelolaan Keuangan Daerah BAB III Pasal 20 bahwa Struktur APBD merupakan satu kesatuan yang terdiri dari: 1) Pendapatan daerah meliputi semua penerimaan uang melalui Rekening Kas Umum Daerah, yang menambah ekuitas dana lancar, yang merupakan hak daerah dalam satu tahun anggaran yang tidak perlu dibayar kembali oleh Daerah, 2) Belanja daerah meliputi semua pengeluaran dari Rekening Kas Umum Daerah yang mengurangi ekuitas dana lancar, yang merupakan kewajiban daerah dalam satu tahun anggaran yang tidak akan diperoleh pembayarannya kembali oleh Daerah, 3) Pembiayaan daerah meliputi semua penerimaan yang perlu dibayar kembali dan/atau pengeluaran yang akan diterima kembali, baik pada tahun anggaran yang bersangkutan maupun pada tahun-tahun anggaran berikutnya.

Permendagri Nomor 13 Tahun 2006 tentang Pedoman Pengelolaan Keuangan Daerah menyebutkan bahwa APBD memiliki fungsi diantaranya 1) Fungsi otorisasi mengandung arti bahwa anggaran daerah menjadi dasar untuk melaksanakan pendapatan dan belanja pada tahun yang bersangkutan, 2) Fungsi perencanaan mengandung arti bahwa anggaran daerah menjadi pedoman bagi manajemen dalam merencanakan kegiatan pada tahun yang bersangkutan, 3) Fungsi pengawasan mengandung arti bahwa anggaran daerah menjadi pedoman untuk menilai apakah kegiatan penyelenggaraan pemerintahan daerah sesuai dengan ketentuan yang telah ditetapkan, 4) Fungsi alokasi mengandung arti bahwa anggaran daerah harus diarahkan untuk menciptakan lapangan kerja atau mengurangi pengangguran dan pemborosan sumber daya, serta meningkatkan efisiensi dan efektivitas perekonomian, 5) Fungsi distribusi mengandung arti bahwa kebijakan anggaran daerah harus memperhatikan rasa keadilan dan kepatutan, 6) Fungsi stabilisasi mengandung arti bahwa anggaran pemerintah daerah menjadi alat untuk memelihara dan mengupayakan keseimbangan fundamental perekonomian daerah.

Berdasarkan PP Nomor 58 Tahun 2005 tentang Pengelolaan Keuangan Daerah dan Kepmendagri Nomor 29 Tahun 2002 tentang Pedoman Pengurusan, Pertanggung jawaban dan Pengawasan Keuangan Daerah serta Tata Cara Penyusunan APBD, Pelaksanaan Tata Usaha Keuangan Daerah dan Penyusunan Perhitungan APBD mengatakan bahwa Anggaran Pendapatan dan Belanja Daerah (APBD) disusun berdasarkan pendekatan kinerja, yaitu suatu system anggaran yang mengutamakan upaya pencapaian hasil kerja dari perencanaan alokasi biaya yang ditetapkan. 


\section{Belanja Modal}

Belanja Modal yang dikemukakan oleh Halim (2007:101) merupakan pengeluaran anggaran untuk perolehan asset tetap dan asset lainnya yang memberikan manfaat lebih dari satu periode akuntansi. Belanja Modal seperti yang disampaikan oleh Nordiawan (2010:71) adalah pengeluaran yang manfaatnya cenderung melebihi satu tahun anggaran dan akan menambah jumlah asset atau kekayaan organisasi sektor publik, yang selanjutnya akan menambah anggaran operasional untuk biaya pemeliharaannya.

Berpedoman pada Peraturan Pemerintah Republik Indonesia No. 71 tahun 2010 tentang Standar Akuntansi Pemerintahan menyebutkan jenis-jenis belanja modal yaitu 1) Belanja Modal Tanah, 2) Belanja Modal Peralatan dan Mesin, 3) Belanja Modal Gedung dan Bangunan, 4) Belanja Modal Jalan, Irigasi, dan Jaringan, 5) Belanja Modal Aset Tetap Lainnya/ Aset non lancar lainnya, 6) Belanja Modal Aset Lainnya.

\section{Pertumbuhan Ekonomi}

Menurut Kuznets pertumbuhan ekonomi adalah kenaikan jangka panjang dalam kemampuan suatu negara untuk menyediakan semakin banyak jenis barangbarang ekonomi kepada penduduknya; kemampuan ini tumbuh sesuai dengan kemajuan teknologi, dan penyesuaian kelembagaan dan ideologis yang diperlukannya (Jhingan, 2010:57). Pertumbuhan ekonomi menurut Sirojuzilam dalam Asmaul, dkk (2013), dinyatakan bahwa pertumbuhan ekonomi adalah suatu daerah bisa dilihat dari nilai PDRB. PDRB (Produk Domestik Regional Bruto) merupakan salah satu indikator ekonomi makro yang dapat memberikan petunjuk sejauh mana perkembangan ekonomi dan struktur ekonomi daerah. Pertumbuhan ekonomi daerah diukur dengan cara menganalisis perubahan kesepakatan kerja agregat secara sektoral dibandingkan dengan perubahan pada sektor yang sama diperekonomian yang dijadikan acuan seperti yang disampaikan oleh Arsyad (2010:389).

Seperti yang dikemukakan oleh Smith (2002:118) terdapat tiga komponen pertumbuhan ekonomi yang mempunyai arti penting bagi setiap masyarakat yaitu: a) Akumulasi modal, termasuk semua investasi baru dalam tanah, peralatan fisik, dan sumberdaya manusia melalui perbaikan dibidang kesehatan, pendidikan, dan keterampilan, b) Pertumbuhan jumlah penduduk dan yang pada akhirnya menyebabkan pertumbuhan angkatan kerja, c) Kemajuan teknologi yang secara luas, diterjemahkan sebagai cara baru untuk menyelesaikan pekerjaan.

\section{Pendapatan Asli Daerah (PAD)}

Pendapatan Asli Daerah (PAD) adalah pendapatan yang diperoleh daerah yang dpungut berdasarkan peraturan daerah sesuai dengan peraturan perundang-undangan, guna keperluan daerah yang bersangkutan dalam pembiayaan kegiatannya (BPS, 2015:15). Pendapat lain disampaikan oleh 
Nordiawan (2007:181) bahwa Pendapatan Asli Daerah merupakan pendapatan daerah yang bersumber dari pemerintah daerah itu sendiri.

Berdasarkan Peraturan Pemerintah Republik Indonesia No. 71 tahun 2010 tentang Standar Akuntansi Pemerintahan disebut bahwa PAD bersumber dari 1) Pajak Daerah, 2) Retribusi Daerah, 3) hasil pengelolaan kekayaan Daerah yang dipisahkan dan 4) lain - lain PAD yang sah. Lain-lain PAD yang sah sebagaimana dimaksud diatas berdasarkan Undang-undang Nomor 33 Tahun 2004 BAB V Pasal 6 ayat 2, meliputi: a) hasil penjualan kekayaan Daerah yang tidak dipisahkan, b) jasa giro, c) pendapatan bunga, d) keuntungan selisih nilai tukar rupiah terhadap mata uang asing dan e) komisi, potongan, ataupun bentuk lain sebagai akibat dari penjualan dan/atau pengadaan barang dan/atau jasa oleh Daerah. Berdasarkan Undang-undang Nomor 33 Tahun 2004 BAB V Pasal 7, disebut bahwa dalam upaya meningkatkan PAD, daerah dilarang: 1) Menetapkan Peraturan Daerah tentang pendapatan yang menyebabkan ekonomi biaya tinggi dan 2) Menetapkan Peraturan Daerah tentang pendapatan yang menghambat mobilitas penduduk, lalu lintas barang dan jasa antar daerah, dan kegiatan impor/ekspor.

\section{Dana Perimbangan}

Nordiawan (2007:48) menyampaikan bahwa dana perimbangan merupakan salah satu komponen pendapatan daerah yang cukup penting. Banyak pemda yang masih mengandalkan sumber pendapatan ini karena jumlah PAD-nya yang kurang mencukupi untuk menutup anggaran belanjanya. Dana Perimbangan menurut BPS (2015:17) adalah dana yang bersumber dari pendapatan APBN yang dialokasikan kepada Daerah untuk mendanai kebutuhan daerah dalam rangka pelaksanaan desentralisasi. Menurut Undang-undang Nomor 33 Tahun 2004 Tentang Perimbangan Keuangan antara Pemerintah Pusat dan Pemerintahan Daerah BAB II Pasal 2 ayat 3 Dana Perimbangan bertujuan mengurangi kesenjangan fiskal antara Pemerintah dan Pemerintahan Daerah dan antarPemerintah Daerah.

Menurut Peraturan Pemerintah Republik Indonesia Nomor 71 Tahun 2010 tentang Standar Akuntansi Pemerintahan bahwa Dana Perimbangan terdiri atas: a) Dana Bagi Hasil Pajak, b) Dana Bagi Hasil Sumber Daya Alam, c) Dana Alokasi Umum dan, d) Dana Alokasi Khusus.

\section{Lain-lain Pendapatan yang Sah}

Lain-lain pendapatan yang sah menurut UU 32 Tahun 2004 pasal 164 ayat 1 tentang pemerintah daerah adalah seluruh pendapatan daerah selain Pendapatan Asli Daerah (PAD), Dana Perimbangan, yang meliputi hibah, dana darurat, dan lain-lain pendapatan yang ditetapkan pemerintah., Lain-lain pendapatan yang sah adalah seluruh pendapatan daerah selain Pendapatan Asli Daerah (PAD), Dana 
Perimbangan, yang meliputi hibah, dana darurat, dan lain-lain pendapatan yang ditetapkan pemerintah seperti yang disampaikan oleh Yuriko (2013:8)

Menurut Peraturan Pemerintah Republik Indonesia Nomor 71 Tahun 2010 tentang Standar Akuntansi Pemerintahan bahwa Lain-lain Pendapatan yang Sah terdiri atas : 1) Pendapatan Hibah, 2) Dana darurat, dan 3) Pendapatan lainnya.

\section{METODE PENELITIAN}

Pendekatan dalam penelitian ini menggunakan pendekatan kuantitatif, bahwa penelitian kuntitatif dapat diartikan sebagai metode penelitian yang dilandaskan pada filsafat positivisme digunakan untuk meneliti pada populasi atau sampel tertentu (Sugiyono, 2007:13) Untuk teknik penelitian yang digunakan dalam penelitian ini adalah teknik statistik deskriptif. Dimana dari data statistik peneliti akan menganalisa dengan cara mendeskripsikan atau menggambarkan data yang telah terkumpul sebagaimana adanya tanpa bermaksud membuat kesimpulan yang berlaku untuk umum atau generalisasi.

Langkah-langkah pengumpulan data yang digunakan dalam penelitian ini adalah dengan melakukan observasi nonpartisipasi pada Badan Pusat Statistik (BPS) Provinsi Jawa Timur tahun 2012-2014 untuk melihat Pengaruh Pertumbuhan Ekonomi, Pendapatan Asli Daerah (PAD), Dana Perimbangan dan Lain-Lain Pendapatan Yang Sah terhadap Pengalokasian Anggaran Belanja Modal pada Pemerintah Daerah Kabupaten/ Kota di Provinsi Jawa Timur Tahun 2012-2014. Adapun populasi dalam penelitian ini adalah Laporan Realisasi Anggaran APBD Seluruh Pemerintah Daerah Kabupaten/ Kota di Provinsi Jawa Timur yang berjumlah 29 Kabupaten dan 9 Kota sejak tahun 20122014 yaitu 38 x 3 tahun yaitu 114. Data penelitian ini di ambil dalam kurun waktu 3 tahun yaitu 20122014 yang diambil dari Badan Pusat Statistik (BPS) Provinsi Jawa Timur. Penentuan sampel ditetapkan dengan Teknik Total Sampling karena setiap kabupaten atau kota telah melaporkan Realisasi Laporan APBD. Jumlah daerah Kabupaten dan Kota di Jawa Timur

Penelitian ini dimaksudkan untuk menganalisis pengaruh Pertumbuhan Ekonomi $\left(\mathrm{X}_{1}\right)$, Pendapatan Asli Daerah (PAD) $\left(\mathrm{X}_{2}\right)$, Dana Perimbangan $\left(\mathrm{X}_{3}\right)$ dan Lain-Lain Pendapatan yang Sah $\left(\mathrm{X}_{4}\right)$ terhadap Pengalokasian Anggaran Belanja Modal (Y).

Berdasarkan Peraturan Pemerintah Republik Indonesia No. 71 tahun 2010 Standar Akuntansi Pemerintahan untuk menghitung belanja modal, peneliti menggunakan rumus :

$$
\mathrm{BM}=\mathrm{BT}+\mathrm{BPM}+\mathrm{BGB}+\mathrm{BJIJ}+\mathrm{BATL}+\mathrm{BAL}
$$


Dimana BT adalah Belanja Tanah, BPM adalah Belanja Peralatan dan Mesin, BGB menyatakan Belanja Gedung dan Bangunan , BJIJ menunjukkan Belanja Jalan, Irigasi, dan Jaringan, BATL adalah Belanja Aset Tetap Lainnya, BAL menunjukkan Belanja Asset Lainnya.

Dalam penelitian ini pertumbuhan ekonomi dihitung dengan menggunakan rumus :

$$
G_{t}=\frac{Y r_{t}-Y r_{t-1}}{Y r_{t-1}} \times 100 \%
$$

Dimana $\mathrm{G}_{\mathrm{t}}$ mencerminkan Tingkat Pertumbuhan Ekonomi yang dinyatakan dengan persen, sedangkan $\mathrm{Yr}_{\mathrm{t}}$ adalah Pendapatan riil pada tahun $\mathrm{t}$, untuk $\mathrm{Yr}_{\mathrm{t}-1}$ mencerminkan Pendapatan riil pada tahun $\mathrm{t}-1$.

Untuk Pendapatan Asli Daerah digunakan rumus:

$$
\mathbf{P A D}=\mathbf{H P D}+\mathrm{HRD}+\mathrm{HPKDD}+\text { LPADS } .
$$

Dimana HPD menunjukkan Pajak Daerah, HRD adalah Retribusi Daerah, PLPD adalah Hasil Pengelolaan Kekayaan Daerah yang Dipisahkan, sedangkan LPADS mencerminkan Lain-lain Pendapatan Asli Daerah yang Sah.

Untuk menghitung dana perimbangan dalam penelitian ini digunakan rumus :

$$
\mathrm{DP}=\mathrm{DBHP}+\mathrm{DBHS}+\mathrm{DAU}+\mathrm{DAK}
$$

dimana DBHP adalah Dana Bagi Hasil Pajak, DBHS menunjukkan Dana Bagi Hasil Sumber Daya Alam, DAU untuk Dana Alokasi Umum dan DAK adalah Dana Alokasi Khusus. Lain-lain Pendapatan yang Sah dihitung dengan rumus $\mathrm{LPS}=\mathrm{PH}+\mathrm{DD}+\mathrm{PL}$, dimana $\mathrm{PH}$ adalah Pendapatan Hibah, DD untuk Dana darurat, dan PL menunjukkan Pendapatan lainnya.

Berdasar tujuan penelitian untuk menganalisis 1). Pengaruh Pertumbuhan Ekonomi terhadap Pengalokasian Anggaran Belanja Modal pada Pemerintah Daerah Kabupaten/ Kota di Provinsi Jawa Timur Tahun 2012-2014, 2). Pengaruh Pendapatan Asli Daerah (PAD terhadap Pengalokasian Anggaran Belanja Modal pada Pemerintah Daerah Kabupaten/ Kota di Provinsi Jawa Timur Tahun 2012-2014, 3). Pengaruh Dana Perimbangan terhadap Pengalokasian Anggaran Belanja Modal pada Pemerintah Daerah Kabupaten/ Kota di Provinsi Jawa Timur Tahun 2012-2014, 4). Pengaruh Lain-lain Pendapatan yang Sah terhadap Pengalokasian Anggaran Belanja Modal pada Pemerintah Daerah Kabupaten/ Kota 
di Provinsi Jawa Timur Tahun 2012-2014, 5). Pengaruh Pertumbuhan Ekonomi, Pendapatan Asli Daerah (PAD), Dana Perimbangan dan Lain-lain Pendapatan yang Sah terhadap Pengalokasian Anggaran Belanja Modal pada Pemerintah Daerah Kabupaten/ Kota di Provinsi Jawa Timur Tahun 2012-2014, Berikut disampaikan kerangka konseptual dalam penelitian ini:

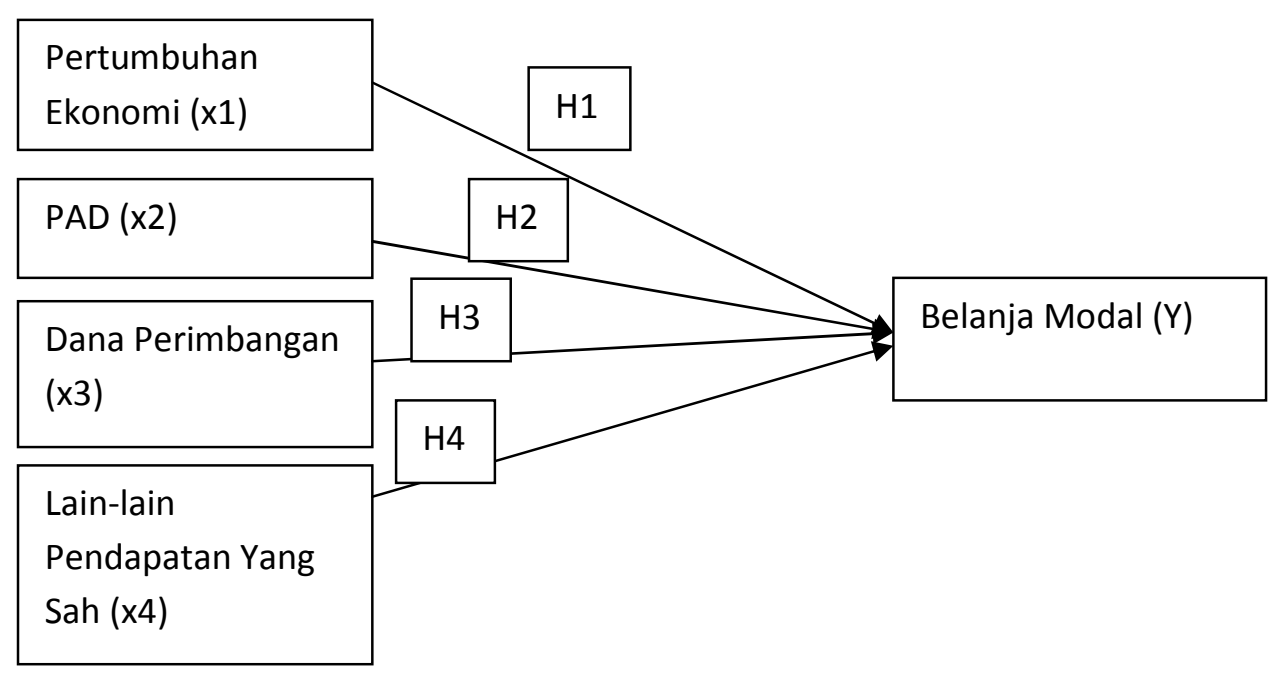

Gambar 1. Model Penelitian

Setelah pengujian secara parsial dari tiap variabel penelitian, maka akan dilakukan pengujian secara simultan.

\section{HASIL DAN PEMBAHASAN}

Analisis deskiptif digunakan peneliti untuk mendeskripsikan masing-masing variabel dalam penelitian. Data yang diperoleh dari Badan Pusat Statistik Provinsi Jawa Timur menunjukkan beberapa kabupaten/ kota di jawa timur memiliki nilai pertumbuhan ekonomi, PAD, dana perimbangan, lain-lain pendapatan yang sah serta belanja modal yang bervariatif.

Untuk menganalisis data, peneliti melakukan uji normalitas dahulu dengan tujuan melihat data telah berdistribusi normal. Hasil uji analisis statistik Kolmogorov-Smirnov test (K-S) dengan menggunakan taraf signifkan sebesar 0,05 menunjukkan nilai signifikan variabel tersebut lebih besar $(0,986)$ dari taraf signifikan yang ditetapkan, yaitu sebesar 0,05 , hasil tersebut menunjukkan bahwa data terdistribusi normal. 
Tabel 1. Hasil Uji Kolmogorov-Smirnov

\begin{tabular}{cc}
\hline Item & Unstandardized Residual \\
\hline $\mathrm{N}$ & 114 \\
Mean & $0 \mathrm{E}-7$ \\
Kolmogorov- Smirnov Z & 0,454 \\
Asymp. Sig. (2-tailed) & 0,986
\end{tabular}

\section{Sumber: Data diolah mandiri}

Hasil Uji multikolinieritas dapat diketahi bahwa variabel $\mathrm{X}_{1}$ memiliki tolerance 0,962 dan VIF sebesar 1,040. Pada variabel $\mathrm{X}_{2}$ dapat diketahui nilai tolerance 0,390 dan VIF sebesar 2,564. Pada $\mathrm{X}_{3}$ dapat diketahui nilai tolerance 0,188 dan VIF sebesar 5,313 Pada $\mathrm{X}_{4}$ dapat diketahui nilai tolerance 0,136 dan VIF sebesar 7,360. Perhitungan nilai Tolerance dan VIF dengan acuan nilai tolerance > 0,10 dan nilai VIF 10, dari hasil tersebut dikatakan bahwa dalam model ini tidak ada multikolinieritas.

Tabel 2. Hasil Uji Multikolinieritas

\begin{tabular}{|c|c|c|c|c|}
\hline Model & \multirow{2}{*}{ T } & Sig. & \multicolumn{2}{|c|}{ Collinearity Statistics } \\
\cline { 4 - 5 } & & & Tolerance & VIF \\
\hline (Constant) &,- 669 &, 505 & & \\
ln_PE & $-1,808$ &, 073 &, 962 & 1,040 \\
ln_PAD & 6,307 &, 000 &, 390 & 2,564 \\
In_DP & 3,484 &, 001 &, 188 & 5,313 \\
In_LPS & 1,834 &, 069 &, 136 & 7,360 \\
\hline
\end{tabular}

Sumber: Data diolah mandiri

Dari tabel pengambilan keputusan autokorelasi menunjukkan bahwa hasil hitung DurbinWatson sebesar 1,777 menunjukkan lebih besar dari batas atas (du) 1,679 dan kurang dari 4-1,679(4du), maka dapat disimpulkan bahwa tidak terdapat autokorelasi.

Tabel 3. Hasil Uji Autokorelasi

\begin{tabular}{cccccc}
\hline Model & $\boldsymbol{R}$ & $\boldsymbol{R}$ square & $\begin{array}{c}\text { Adjusted R } \\
\text { Square }\end{array}$ & $\begin{array}{c}\text { Std. Error of the } \\
\text { Estimate }\end{array}$ & $\begin{array}{c}\text { Durbin- } \\
\text { Watson }\end{array}$ \\
\hline 1 & 0,897 & 0,805 & 0,798 & 0,26247 & 1,777 \\
\hline
\end{tabular}

Sumber: Data diolah mandiri 
Persamaan regresi linier berganda yang diperoleh dari hasil uji analisis yaitu :

$$
\mathrm{Y}=-1,188-0,159 \mathrm{X}_{1}+0,311 \mathrm{X}_{2}+0,536 \mathrm{X}_{3}+0,199 \mathrm{X}_{4}
$$

Tabel 4.Hasil Analisis Koefisien Determinasi

\begin{tabular}{ccccc}
\hline Model & $\boldsymbol{R}$ & $\boldsymbol{R}$ square & $\begin{array}{c}\text { Adjusted R } \\
\text { Square }\end{array}$ & $\begin{array}{c}\text { Std. Error of the } \\
\text { Estimate }\end{array}$ \\
\hline 1 & 0,897 & 0,805 & 0,798 & 0,26247 \\
\hline
\end{tabular}

Sumber: Data diolah mandiri

Uji Koefisien determinasi untuk mengukur derajat hubungan antara tiap variabel $\mathrm{X}$ terhadap nilai variabel Y secara parsial. Dari hasil Analisis Koefisien Determinasi diperoleh Nilai Adjusted RSquare sebesar 0,798. menunjukkan bahwa pertumbuhan ekonomi, pendapatan asli daerah, dana perimbangan dan lain-lain pendapatan yang sah terhadap pengalokasian belanja modal sebesar 79,8\% dan sisanya yaitu 20,2\% dipengaruhi oleh faktor lain yang tidak dikaji dalam penelitian ini.

Pertumbuhan Ekomnomi merupakan nilai tambah bruto seluruh barang dan jasa yang tercipta atau dihasilkan di wilayah domestik suatu negara yang timbul akibat berbagai aktivitas ekonomi dalam suatu periode tertentu tanpa memperhatikan apakah faktor produksi yang dimiliki residen atau non residen. Berdasarkan hasil pengujian secara parsial menggunakan uji t yang nilainya akan dibandingkan dengan signifikansi 0,05 dapat diketahui pada output regresi menunjukkan bahwa angka signifikansi variabel Pertumbuhan Ekonomi sebesar 0,073. Hal tersebut berarti tidak terdapat pengaruh yang signifikan secara parsial dari Petumbuhan Ekonomi terhadap Pengalokasian Anggaran Belanja Modal pada Kabupaten/ Kota di Jawa Timur. Hasil ini sesuai dengan penelitian yang dilakukan oleh Darwanto dan Yulia Yustikasari (2007) yang menyatakan bahwa Pertumbuhan ekonomi tidak berpengaruh terhadap Pengalokasian Belanja Modal.

Pendapatan Asli Daerah adalah pendapatan yang diperoleh Daerah yang dipungut berdasarkan Peraturan Daerah yang berlaku, guna keperluan daerah yang bersangkutan dalam pembiayaan kegiatannya. Pada output regresi menunjukkan bahwa angka sigifikansi untuk variabel Pendapatan Asli Daerah sebesar 0,000 artinya terdapat pengaruh yang signifikan secara parsial dari Pendapatan Asli Daerah terhadap Pengalokasian Anggaran Belanja Modal pada Kabupaten/Kota di Jawa Timur. Hal tersebut sejalan dengan hasil penelitian yang dilakukan oleh Dini Arwati dan Novita Hadiati (2013) yang menghasilkan bahwa Pendapatan Asli Daerah berpengaruh terhadap pengalokasian anggaran belanja modal.

Dana perimbangan merupakan sumber pendapatan daerah yang berasal dari APBN yang mendukung pelaksanaan kewenangan pemerintah daerah dalam mencapai tujuan pemberian otonomi 
kepada daerah, yaitu terutama untuk peningkatan pelayanan dan kesejahteraan masyarakat. Pada output regresi menunjukkan angka sigifikansi untuk variabel Dana Perimbangan sebesar 0,001 artinya terdapat pengaruh yang signifikan secara parsial dari Dana Perimbangan terhadap Pengalokasian Anggaran Belanja Modal pada Kabupaten/Kota di Jawa Timur. hasil ini mendukung dengan hasil penelitian yang dilakukan oleh Darwanto dan Yulia Yustikasari (2007) pada pemerintah daerah seJawa Bali, yaitu Dana Alokasi Umum (DAU) yang berpengaruh signifikan terhadap Pengalokasian Anggaran Belanja Modal.

Lain-lain Pendapatan yang Sah adalah pendapatan lainnya dari pemerintah pusat dan/atau dari instansi pusat, serta dari daerah lainnya. Output regresi menunjukkan bahwa angka sigifikansi untuk variabel Lain-lain Pendapatan yang Sah sebesar 0,069 berarti tidak terdapat pengaruh yang signifikan secara parsial dari Lain-lain Pendapatan yang Sah terhadap Pengalokasian Anggaran Belanja Modal pada Kabupaten/Kota di Jawa Timur. hasil ini mendukung dengan hasil penelitian yang dilakukan oleh Sri Suwarni (2009) menunjukkan bahwa lain-lain pendapatan yang sahberpengaruh signifikan positif terhadap belanja daerah.

Pengujian secara simultan menggunakan uji F yang nilainya akan dibandingkan dengan signifikansi 0,05 atau 5\% dengan hasil seperti dibawah

Tabel 5. Hasil Uji F (Simultan)

\begin{tabular}{|l|r|r|r|c|c|}
\hline Model & Sum of Squares & df & Mean Square & F & Sig. \\
\hline Regression & 31,055 & 4 & 7,764 & 112,701 &, $000^{\mathrm{b}}$ \\
1 Residual & 7,509 & 109 &, 069 & & \\
Total & 38,564 & 113 & & & \\
\hline
\end{tabular}

Sumber: Data diolah mandiri

Hasil yang diperoleh dari perbandingan $\mathrm{F}$ hitung dengan $\mathrm{F}$ tabel adalah $\mathrm{F}_{\text {hitung }}>\mathrm{F}_{\text {tabel }}$ $(112,701>2,45)$, maka pada tingkat kekeliruan 5\% Ho ditolak dan Ha diterima yang berarti keempat variabel bebas yaitu Pertumbuhan Ekonomi, Pendapatan Asli Daerah, Dana Perimbangan, dan lainlain Pendapatan yang Sah secara simultan berpengaruh positif terhadap belanja modal.

\section{KESIMPULAN}

Berdasarkan hasil penelitian dapat diambil kesimpulan bahwa hasil uji asumsi klasik, berdasarkan analisis grafik dan statistik bahwa data telah terdistribusi normal. Model regresi telah memenuhi asumsi normalitas. Model ini juga tidak ada masalah multikolinieritas dan tidak terdapat 
masalah autokorelasi. Persamaan regresi ini juga tidak terjadi heteroskedastisitas. Sehingga dapat disimpulkan bahwa model ini telah memenuhi syarat uji asumsi klasik dalam model regresi linier berganda.

Hasil pengujian hipotesis menunjukkan secara parsial pertumbuhan ekonomi tidak berpengaruh signifikan terhadap pengalokasian anggaran belanja modal, untuk Pendapatan Asli Daerah berpengaruh signifikan terhadap pengalokasian belanja modal, hal ini berarti jika pendapatan asli daerah mengalami kenaikan maka pengalokasian anggaran belanja modal meningkat. Dana Perimbangan berpengaruh positif terhadap pengalokasian anggaran belanja modal, hal ini berarti jika dana perimbangan mengalami kenaikan maka pengalokasian anggaran belanja modal meningkat. Lain-lain pendapatan yang sah tidak berpengaruh signifikan terhadap pengalokasian belanja modal. Hasil pengujian hipotesis menunjukkan hasil perhitungan statistik uji f dengan hasil nilai signifikansi sebesar 0,000 berada dibawah 0,05 yang berarti secara simultan menunjukkan bahwa seluruh variabel independen tersebut (variabel Pertumbuhan Ekonomi, Pendapatan Asli Daerah, Dana Perimbangan dan Lain-lain Pendapatan yang Sah) berpengaruh signifikan terhadap variabel Belanja Modal.

\section{SARAN}

Bagi Pembuat kebijakan oleh Pemerintah Daerah dan Pemerintah Pusat temuan-temuan dalam penelitian ini menunjukkan beberapa hal yang secara teoritis dapat dipahami dan dikaji. Namun, dalam tataran praktis masih perlu didiskusikan kembali, mengingat adanya beberapa faktor yang tidak dimasukkan di dalam analisis (misalnya aspek psikologis dan personalitas pembuat keputusan di pemerintah daerah). Bagi peneliti berikutnya alangkah baiknya untuk periode waktu yang digunakan dalam rentan lima tahun sehingga akan menunjukkan hasil yang lebih mewakili.

\section{DAFTAR PUSTAKA}

Arsyad, Licolin. 2010. Ekonomi Pembangunan. Edisi 5. Yogyakarta. STIM YKPN Yogyakarta.

Arwati, Dini dan Novita Hadiati. 2013. Pengaruh Pertumbuhan Ekonomi, Pendapatan Asli Daerah dan Dana Alokasi Umum Terhadap Pengalokasian Anggaran Belanja Modal pada Pemerintah Daerah. SEMATIK 2013. ISBN 979-26-0266-6

Badan Pusat Statistik. 2014. Statistik Keuangan Pemerintah Kabupaten/Kota 2012-2013. Jakarta: Cv. Ryan Indah

Badan Pusat Statistik. 2015. Statistik Keuangan Pemerintah Kabupaten/ Kota 2013-2014. Jakarta: Cv. Ryan Indah 
Badan Pusat Statistik. 2016. Statistik Keuangan Pemerintah Kabupaten/ Kota 2014-2015. Jakarta: Cv. Ryan Indah

Badan Pusat Statistik. 2015. Produk Domestik Regional Bruto Kabupaten/ Kota di Jawa Timur menurut Lapangan Usaha 2010-2014. Jakarta: Cv. Bima Media Mandiri.

Boediono. 1985. Teori Pertumbuhan Ekonomi. Penerbit BPFE. Yogyakarta.

Darwanto, Yulia Yustikasari. 2007. Pengaruh Pertumbuhan Ekonomi, Pendapatan Asli Daerah dan Dana Alokasi Umum terhadap Pengalokasian Anggaran Belanja Modal, Simposium Nasional Akuntansi X, Makasar, 26-27 Juli 2007.

Ghozali, Imam. 2013. Aplikasi Analisis Multivariate dengan Program SPSS. Edisi 7. Badan Penerbitan Universitas Diponegoro, Semarang.

Halim, Abdul. 2001. Manajemen Keuangan Daerah (Bunga Rampai). Penerbit UPP AMP YKPN. Yogyakarta.

Julitawati, Ebit, Darwanis dan Jalalluddin. 2012. Pengaruh Pendapatan Asli Daerah (PAD) dan Dana Perimbangan terhadap Kinerja Keuangan Pemerintah Kanupaten/ Kota di Provinsi Aceh. Junal Akuntansi Pascasarjana Universitas Syiah Kuala. Vol. 2, No. 1, Hal 25-29

Keputusan Menteri Dalam Negeri Nomor 13 Tahun 2006 Tentang Anggaran Pendapatan dan Belanja.

Mardisimo. 2009. Akuntansi Sektor Publik. Yogyakarta: Andi

Mawarni, Darwis. Syukry Abdullah. 2013. Pengaruh Pendapatan Asli Daerah dan Dana Alokasi Umum terhadap Belanja Modal serta Dampaknya terhadap Pertumbuhan Ekonomi Daerah (Studi pada Kabupaten dan Kota di Aceh). Jurnal Akuntansi. Pascasarjana Universitas Syiah Kuala. Vol 2. No. 2. Hal 80-90.

Noordiawan, Deddi. dkk. 2007. Akuntansi Pemerintahan. Jakarta: Salemba Empat

Noordiawan, Deddi. dkk. 2008. Akuntansi Sektor Publik. Edisi 2. Jakarta: Salemba Empat.

Noordiawan, Deddi. dkk. 2009. Akuntansi Pemerintahan. Jakarta: Salemba Empat

Noordiawan. Deddi. dkk. 2010. Edisi 2. Akuntansi Sektor Publik. Jakarta: Salemba Empat

Peraturan Pemerintah Republik Indonesia Nomor 24 Tahun 2005 tentang Standar Akuntansi Pemerintahan. 
Peraturan Pemerintah Republik Indonesia Nomor 58 tahun 2005 tentang Pengelolaan Keuangan Daerah.

Peraturan Pemerintah Dalam Negeri Nomor 13 Tahun 2006 Tentang Pedoman Pengelolaan Keuangan Daerah.

Peraturan Menteri Keuangan Nomor 91/PMK.06/2007 tentang Bagan Akun Standar

Peraturan Pemerintah Republik Indonesia Nomor 71 Tahun 2010 tentang Standar Akuntansi Pemerintah

Peraturan Pemerintah Republik Indonesia Nomor 64 Tahun 2013 tentang Jenis Dan Tarif Atas Jenis Penerimaan Negara Bukan Pajak Yang Berlaku Pada Kementerian Dalam Negeri

Putu, I. Ngurah Panji Kartika Jaya dan A.A.N.B Dwiradia. 2014. Pengaruh Pendapatan Asli Daerah pada Belanja Modal dengan Pertumbuhan Ekonomi sebagai Variabel Pemoderasi. Jurnal Akuntansi. Universitas Udayana. Vol 7, No. 1. Hal 79-92

Riduwan. 2013. Dasar-dasar Statistika Edisi Revisi. Bandung: CV. Alfabeta

Sugiyono. 2011. Metode Penelitian Kuantitatif, Kualitatif dan R\&D. Bandung: CV. Alfabeta.

Sunyoto, Danang. 2013. Metode dan Instrumen Penelitian cetakan pertama. Jakarta: PT. Buku Seru

Suwarni, Sri. 2009. Pengaruh Pendapatan Asli Daerah (PAD). Lain-lain Pendapatan yang Sah (LPS), Dana Alokasi Umum (DAU), dan Dana Bagi Hasil (DBH) terhadap Pengalokasian Anggaran Belanja Modal Pemerintah Daerah (Studi Empiris pada Pemerintah Kabupaten/Kota di Pulau Kalimantan Tahun 2005-2007. Jurnal Akuntansi-F1306612. Fakultas Ekonomi dan Bisnis. UNS. Surakarta.

Ulum, MD. Ihyaul.2008. Akuntansi Sektor Publik. Cetakan ketiga. Malang: UMM Press

Undang-undang Nomor 32 Tahun 2004 tentang Pemerintahan Daerah

Undang-undang Nomor 33 Tahun 2004 tentang Dana Perimbangan Keuangan antara Pemerintah Pusat dan Daerah. 